\title{
ANALISA SWOT DALAM FUNGSI MANAJEMEN UNTUK PENGEMASAN PRODUK BERBASIS TEKNOLOGI INFORMASI DI UNIT PELAKSANA TEKNIS (UPT) PERPUSTAKAAN UNIVERSITAS RIAU
}

\author{
Yuhelmi
}

\author{
yuhelmi@unilak.ac.id
}

\begin{abstract}
This study aims to determine the process of planning, organizing, implementation, and evaluation in the packaging of information technology-based products that have been run in UPT Library University of Riau and the constraints faced when packaging ITbased products are implemented. The type of research used is descriptive evaluative type, ie to an already running program (Ex Post Program Evaluation). Respondents in this research are 3 staffs involved in planning process, organizing, implementing and evaluating product based on information technology and 3 person of leadership as reinforcement result of this research. It must be aware of its strengths and weaknesses, which then think and plan what needs to be done for further improvement. The results showed that Planning, organizing and implementation and evaluation in packaging of products based on Information Technology in UPT Library University of Riau has not been fully implemented well this is due to technical constraints.
\end{abstract}

Keyword: SWOT Analysis, Function Management, Packaging Products, based on information technology, UPT library University of Riau

\begin{abstract}
Abstrak
Penelitian ini bertujuan untuk mengetahui proses perencanaan, pengorganisasian, pelaksanaan, dan evaluasidalam pengemasan produk berbasis teknologi informasi yang telah dijalankan di UPT Perpustakaan Universitas Riau serta kendala yang dihadapi saat pengemasan produk berbasis IT tersebut dilaksanakan. Jenis penelitian yang digunakan adalah jenis deskriptif evaluatif, yaitu terhadap suatu program yang sudah berjalan (Ex Post Program Evaluation). Responden dalam penelitian ini adalah 3 staf yang terlibat dalam proses perencanaan, penggorganisasian, pelaksanaan dan pengevaluasian produk berbasis teknologi informasi serta 3 orang pimpinan sebagai penguat hasil penelitian ini. Harus disadari kekuatan dan kelemahannya, yang selanjutnya berpikir dan merencanakan apa yang harus dilakukan untuk perbaikan selanjutnya. Hasil penelitian menunjukkan bahwa Perencanaan, pengorganisasian dan pelaksanaan serta pengevaluasian dalam pengemasan produk berbasis Teknologi Informasi di UPT Perpustakaan Universitas Riau belum sepenuhnya dapat terlaksana dengan baik ini disebabkan kendala-kendala yang bersifat teknis.
\end{abstract}


Kata kunci : Analisa SWOT, Fungsi Manajemen, Pengemasan Produk, berbasis teknologi informasi, UPT perpustakaan Universitas Riau

\section{PENDAHULUAN}

Agar tujuan pendidikan tinggi tercapai maka keberadaan suatu perguruan tinggi harus ditunjang dengan adanya perpustakaan. Di sini kedudukan perpustakaan adalah penting sebagai pintu gerbang informasi untuk menunjang proses belajar mengajar, penelitian, dan pengabdian masyarakat (Tri Dharma Perguruan Tinggi). Menurut Lasa Hs, perpustakaan merupakan sistem informasi yang didalamnya terdapat aktivitas pengumpulan, pengolahan, pengawetan, pelestarian dan penyajian, serta diseminasi informasi. Informasi meliputi produk intelektual dan artistik manusia. ${ }^{1}$ Saat ini perkembangan ilmu pengetahuan termasuk ilmu perpustakaan dan informasi, secara berangsur-angsur menghendaki adanya perubahan dalam pengelolaan perpustakaan. Perpustakaan tidak hanya sebagai lembaga yang mengumpul, mengelola, menyimpan, dan melestarikan bahan pustaka, tetapi lebih mengutamakan pada penyebaran informasi (dissemination of information).

Menyadari pentingnya perkembangan teknologi informasi dan komunikasi (information and communication technology) membawa perubahan dalam dunia perpustakaan, maka perpustakaan memerlukan kerjasama dengan beberapa stakeholders.

UPT perpustakaan Universitas Riau telah manggunakan otomasi perpustakaan beberapa tahun terakhir dengan program Slims secara terintegrasi. Artinya dari proses pengolahan, pelayanan, dan penelusuran dapat digunakan secara bersamaan dan saling kait mengkait. Namun demikian masih ada kendala yang dihadapi, yaitu belum adanya networking dengan perpustakaan fakultas di lingkungan Universitas Riau. Mencermati betapa pentingnya perpustakaan dalam memberikan layanandengan cepat dan tepat, selayaknya perlu ditumbuh kembangkan melalui berbagai program dan kegiatan yang realistis sehingga dapat mencapai sasaran yang dikehendaki.Untuk itu UPT Perpustakaan Universitas Riau bekerjasama dengan pihak UPT Puskom Universitas Riau membangun database baru yang berbasis web. Dengan harapan ke depan semua jenis koleksi yang ada di UPT Perpustakaan Universitas Riau dan perpustakaan fakultas di lingkungan Universitas Riau dapat terakses melalui internet dengan informasi yang realtime (pada saat itu juga), sehingga pengguna akan mendapatkan kepuasan layanan yang beragam secara relevan, akurat, dan cepat. Jenis layanan informasi yang di tujukan ke khalayak adalah produk-produk yang dihasilkan dan diolah oleh UPT Perpustakaan Universitas Riau, baik produk dalam bentuk tercetak maupun elektronik. Untuk produk informasi tercetak salah satu sumbernya didapatkan melalui kegiatan exhibitions atau pameran buku. Untuk kemudian produk akan diproses dan dilayankan secara online katalog melalui media intranet dan internet. Media online katalog ini dikembangkan bekerjasama dengan pihak UPT Puskom Universitas Riau. Sedangkan produk dalam bentuk elektronik seperti e-journal, UPT Perpustakaan Universitas Riau bekerjasama dengan pihak lain. Kerjasama pihak

\footnotetext{
${ }^{1}$ Lasa Hs. Manajemen Perpustakaan. Yogyakarta : Gama Media, 2005. hal. 48
} 
perpustakaan dengan stakeholder ini meliputi, yaitu pihak rektorat sebagai pemegang kebijakan, sivitas akademika sebagai pengguna, UPT Puskom Universitas Riau sebagai mitra kerja dalam pengembangan layanan berbasis teknologi informasi, dan beberapa penerbit/distributor sebagai mitra kerja dalam pengadaan dan pengembangan koleksi. Dari gambaran di atas menunjukkan bahwa keberadaan produk informasi dalam bentuk elektronik pada jasa pelayanan informasi di perpustakaan sangat diperlukan.

Salah satu upaya yang dilakukan UPT Perpustakaan Universitas Riau adalah melakukan pengemasan produk berbasis teknologi informasi. Namun sebaik apapun produk dan layanan perpustakaan, tidak akan banyak gunanya bila tidak banyak orang yang tahu dan menggunakannya. Karena itu diperlukan sebuah proses yang bernama pemasaran (marketing). Dalam memasarkan produk dan jasa layanan perpustakaan, maka perlu suatu strategi komunikasi pemasaran, yaitu dengan bauran pemasaran (marketing mix) yang terdiri dari product, price, place dan promotion. Atau bisa dikatakan bahwa promosi merupakan elemen penting dari bauran pemasaran. Secara umum promosi dilakukan melalui beberapa elemen (promotion mix), salah satunya adalah melalui pengemasan produk. ${ }^{2}$

Promosi perpustakaan perlu dilakukan supaya seluruh aktivitas yang berhubungan dengan jasa perpustakaan dapat diketahui dan dipahami oleh pengguna. Promosi merupakan salah satu komponen pemasaran, dengan mempromosikan kelembagaan, koleksi, sistem dan jenis pelayanan, maka terjadilah proses pendekatan informasi kepada pengguna.

Agar promosi efektif maka diperlukan sebuah perencanaan, pengorganisaian, dan pelaksanaanyang baik, selanjutnya dilakukan evaluasi pada periode waktu tertentu. Sehingga sasaran yang ingin dicapai dapat terlaksana tepat waktu, tepat cara, dan tepat sasaran. Berdasarkan kajian model pengemasan produk berbasis teknologi informasi tersebut, akan diketahui kekuatan, kelemaham, kesempatan, dan ancaman. Analisis SWOT adalah metode perencanaan strategis yang digunakan untuk mengevaluasi kekuatan (strengths), kelemahan (weaknesses), peluang (opportunities), dan ancaman (threats) dalam suatu proyek atau suatu spekulasi bisnis. Keempat faktor itulah yang membentuk akronim SWOT (strengths, weaknesses, opportunities, dan threats). Proses ini melibatkan penentuan tujuan yang spesifik dari spekulasi bisnis atau proyek dan mengidentifikasi faktor internal dan eksternal yang mendukung dan yang tidak dalam mencapai tujuan tersebut

Di sini peneliti tertarik untuk melakukan kajian pengemasan produk berbasis teknologi informasi yang dilakukan oleh UPT Perpustakaan Universitas Riau dikarenakan melihat fenomena pergeseran orientasi kebutuhan pengguna akan informasi berbasis teknologi informasi seiring dengan perkembangan teknologi dan ilmu pengetahuan yang begitu cepat. Untuk itu perlu dilakukan inovasi berbasis kebutuhan pemakai.

\section{TINJAUAN PUSTAKA}

\subsection{Analisa SWOT}

\footnotetext{
${ }^{2}$ PR Smith. Marketing Communications: An Integrated Approach. London: Kogan Page, 1998. P. 7
} 
Metode SWOT pertama kali digunakan oleh Albert Humphrey yang melakukan penelitian di Stamford University pada tahun 1960-1970 dengan analisa perusahaan yang bersumber dalam Fortune500. Meskipun demikian, jika ditarik lebih ke belakang analisa ini telah ada sejak tahun 1920-an sebagai bagian dari Harvard Policy Model yang dikembangkan di Harvard Business School. Namun, pada saat pertama kali digunakan terdapat beberapa kelemahan utama di antaranya analisa yang dibuat masih bersifat deskriptif serta belum bahkan tidak menghubungkan dengan strategi-strategi yang mungkin bisa dikembangkan dari analisis kekuatan-kelemahan yang telah dilakukan.

Dalam melakukan analisis terhadap fungsi-fungsi dan faktor-faktornya, maka berlaku ketentuan berikut: untuk tingkat kesiapan yang memadai, artinya, minimal memenuhi kriteria kesiapan yang diperlukan untuk mencapai sasaran, dinyatakan sebagai kekuatan bagi faktor internal atau peluang bagi faktor eksternal. Sedangkan tingkat kesiapan yang kurang memadai, artinya, tidak memenuhi kriteria kesiapan minimal, dinyatakan sebagai kelemahan bagi faktor internal atau ancaman bagi faktor eksternal.

Untuk menentukan kriteria kesiapan, diperlukan kecermatan, kehati-hatian, pengetahuan, dan pengalaman yang cukup agar dapat diperoleh ukuran kesiapan yang tepat. Kelemahan atau ancaman yang dinyatakan pada faktor internal dan faktor eksternal yang memiliki tingkat kesiapan kurang memadai, disebut persoalan. Selama masih adanya fungsi yang tidak siap atau masih ada persoalan, maka sasaran yang telah ditetapkan diduga tidak akan tercapai. Oleh karena itu, agar sasaran dapat tercapai, perlu dilakukan tindakan-tindakan untuk mengubah fungsi tidak siap menjadi siap. Tindakan yang dimaksud disebut langkah-langkah pemecahan persoalan, yang pada hakekatnya merupakan tindakan mengatasi kelemahan atau ancaman agar menjadi kekuatan atau peluang.

Setelah diketahui tingkat kesiapan faktor melalui analisis SWOT, langkah selanjutnya adalah memilih alternatif langkah-langkah pemecahan persoalan, yakni tindakan yang diperlukan untuk mengubah fungsi yang tidak siap menjadi fungsi yang siap dan mengoptimalkan fungsi yang telah dinyatakan siap.

Oleh karena kondisi dan potensi Perpustakaan berbeda-beda antara satu dengan lainnya, maka alternatif langkah-langkah pemecahan persoalannya pun dapat berbeda, disesuaikan dengan kesiapan sumberdaya manusia dan sumberdaya lainnya di perpustakaan tersebut. Dengan kata lain, sangat dimungkinkan suatu perpustakaan mempunyai langkah pemecahan yang berbeda dengan perpustakaan lain untuk mengatasi persoalan yang sama.

\subsection{Pemasaran}

Pemasaran berhubungan dengan mengidentifikasi dan memenuhi kebutuhan manusia dan masyarakat. Salah satu dari definisi pemasaran terpendek adalah "memenuhi kebutuhan secara menguntungkan". Suatu proses sosial dan manajerial yang membuat individu dan kelompok memperoleh apa yang mereka butuhkan dan inginkan, lewat penciptaan dan pertukaran segala sesuatu yang bernilai dengan orang atau kelompok lain.

American Marketing Association (AMA) merilis definisi terbaru mengenai pemasaran pada tahun 2004 yang menyebutkan :

Pemasaran adalah fungsi organisasi dan serangkaian proses menciptakan, mengkomunikasikan, dan menyampaikan nilai bagi para pelanggan sedemikian rupa sehingga memberikan manfaat bagi organisasi dan para 


\section{stakeholders-nya. ${ }^{3}$}

Selain itu perlu suatu komunikasi dengan konsumen. Hal inilah yang melatar belakangi perlu suatu aplikasi komunikasi dalam pemasaran. Komunikasi pemasaran memegang peranan yang sangat penting bagi pemasar. Tanpa komunikasi, konsumen maupun masyarakat secara keseluruhan tidak akan mengetahui keberadaan produk di pasar.. Dalam menjalankan program komunikasi pemasaran, diperlukan suatu perencanaan secara matang.

Dalam pemasaran sumber berarti pihak yang mengirim pesan pemasaran kepada konsumen. Proses selanjutnya yaitu pemasar menentukan bagaimana pesan itu disusun agar bisa dipahami dan direspons secara positif oleh penerima dalam hal ini konsumen. Dalam proses tersebut ditentukan pula jenis komunikasi apa yang akan digunakan. Apakah pesan akan disampaikan melalui iklan, personal selling, promosi, hubungan masyarakat atau dengan direct marketing. Keseluruhan proses dari perancangan pesan sampai penentuan jenis promosi disebut proses encoding

Proses selanjutnya yaitu menyampaikan pesan melalui media (cetak/elektronik). Proses penyampaian pesan melaui media ini disebut proses transmisi. Pesan yang disampaikan melalui media akan ditangkap oleh penerima dengan respon positif atau negatif. Respon positif identik dengan terjadinya keserasian antara harapan pengirim pesan dengan tanggapan penerima pesan. Proses memberikan respon dan menginterpretasikan pesan yang diterima disebut sebagai proses decoding.

Menurut Tjiptono, tujuan utama dari promosi adalah menginformasikan, mempengaruhi, dan membujuk, serta mengingatkan pelanggan sasaran tentang perusahaan dan bauran pemasarannya. ${ }^{4}$ Secara singkat promosi berkaitan dengan upaya untuk mengarahkan seseorang agar dapat mengenal produk perusahaan, lalu memahaminya, berubah sikap, menyukai, yakin, kemudian akhirnya membeli dan selalu ingat akan produk tersebut. Promosi terutama diarahkan pada calon pembeli yang sudah dikenal atau diketahui secara pribadi.

Berbagai strategi pemasaran dapat dilaksanakan untuk memasarkan produk atau jasa suatu organisasi. Strategi yang dirancang mungkin berbeda dengan organisasi lain, walaupun bahan-bahan dan ramuannya sama. Dalam konsep pemasaran dinamis, menurut Regis Mckena, terdapat tiga strategi pokok yang harus dilakukan, yaitu $;^{5}$

1. Meraih posisi produk (product positioning)

2. Meraih posisi pasar (market positionong)

3. Meraih posisi organisasi (corporate positioning)

Dalam tahap pertama yaitu meraih posisi produk, perpustakaan harus menetapkan produknya yaitu informasi seperti apa yang dibutuhkan atau diinginkan pasar. Apakah sekedar meminjamkan dokumen saja, apakah pasar menghendaki informasi berupa, indeks, katalog induk, abstrak, informasi terseleksi, penelusuran sumber-sumber dalam negeri dan luar negeri, atau jenis informasi berbasis internet. Pustakawan harus peka terhadap kebutuhan pasar

\footnotetext{
${ }^{3}$ Fandy Tjiptono. Pemasaran Strategik. Yogyakarta: Andi, 2008. hal. 5

${ }^{4}$ Fandy Tjiptono,Strategi Pemasaran Yogyakarta : andi Offset,1995. Hal.200

${ }^{5}$ Badollahi Mustafa. Promosi Jasa perpustakaan. Jakarta: Universitas Terbuka, 1996. hal. 6
} 
(pengguna) tentang produk informasi (layanan) yang mereka butuhkan.

Sedangkan pada tahap ke-dua yaitu memperoleh posisi adalah memperoleh pengakuan dari kancah pasar. Dengan kata lain upaya ini bertujuan untuk mencapai kredibilitas produk dan jasa di mata pengguna. Kredibilitas adalah kunci bagi keseluruhan proses mencapai posisi pasar. Kredibilitas ini diperoleh pada saat produk dilemparkan ke kancah pasar dan dianggap oleh pengguna mampu mengatasi permasalahan atau kesulitan yang mereka hadapi. Dengan kata lain produk memberi kepuasan pada pengguna, hal ini akan berdampak secara otomatis dengan adanya komunikasi dari mulut ke mulut.

Dalam tahap ketiga yaitu meraih posisi organisasi, sangat ditentukan oleh keberhasilan manajemen dalam mengelola perpustakaan tersebut. Manajemen yang baik adalah berpegang pada teori-teori manajeman yang benar dan diwarnai dengan gaya menajemen yang tepat

\subsection{Promosi Perpustakaan}

Promosi perpustakaan adalah upaya mengenalkan seluruh aktivitas yang ada di perpustakaan agar diketahui oleh khalayak umum.

Salah satu faktor penting terhadap keberhasilan pemasaran jasa perpustakaan adalah promosi. Sebagai dasar pemikiran untuk melakukan kegiatan promosi adalah komunikasi, karena dengan adanya komunikasi diharapkan terjadi interaksi antara produsen dengan konsumen. Komunikasi akan berjalan dengan baik apabila pesan yang diterima sama dengan pesan yang dikirim. Karena itu, produsen suatu produk atau jasa harus melintasi jalur tersebut untuk mengkomunikasikan produk ke pengguna atau calon konsumen.

Promosi perpustakaan merupakan rangkaian kegiatan perpustakaan yang dirancang agar masyarakat mengetahui manfaat sebuah perpustakaan melalui koleksi, fasilitas, dan produk/layanan yang disediakan. ${ }^{6}$

Di dalam proses pemilihan alat-alat promosi yang digunakan, tergantung pada siapa yang akan dijangkau, apa yang akan ditawarkan,apa yang akan dikomunikasikan, dan bagaimana audien menanggapai pesan. Juga tergantung pada kekuatan (Strenghts) dan kelemahan (Weaknesses) internal organisasi disamping peluang (Opportunities) dan tantangan (Threats) eksternal organisasi. Sebenarnya secara sadar ataupun tidak pustakawan sudah banyak melakukan promosi, akan tetapi kegiatan tersebut tidak/belum terencana sehingga tidak/belum mencapai tujuan maupun sasaran perpustakaan. Menurut pengamatan penulis ada beberapa alat promosi yang digunakan oleh UPT Perpustakaan Universitas Riau, yaitu : brosur, exhibition (pameran), orientasi mahasiswa baru, seminar perpustakaan, pelatihan otomasi perpustakaan, packaging atau pengemasan (CD interaktif, digital library, ejournal, katalog online). Namun dalam penelitian ini peneliti membatasi kajian melalui media promosi dalam bentuk packaging (digital library, e-journal, dan katalog online).

\subsection{Pengemasan Produk Perpustakaan}

Pengemasan informasi adalah kegiatan yang dimulai dari menyeleksi

\footnotetext{
${ }^{6}$ Yuhelmi, Y., \& Rosman, H. (2015). Evaluasi Promosi di Perpustakaan Soeman HS Pekanbaru. Jurnal Ilmu Budaya, 12(1), 45-57.
} 
berbagai informasi dari sumber yang berbeda, mendata informasiyang relevan, menganalisis, mensintesa, dan menyajikan informasi yang sesuai dengan kebutuhan pemakai. Informasi yang dikemas kembali memberi kemudahan dalam penyebaran informasi dan temu kembali informasi. ${ }^{7}$

Jadi pengemasan merupakan sebuah usaha mengemas kembali dalam bentuk yang lebih baik dan menarik. Betapapun lengkapnya suatu koleksi informasi, tidak akan memberikan manfaat bila tidak dikemas kembali dan dikomunikasikan ke pengguna aktual maupun potensial. Harus diakui bahwa kualitas barang ataupun jasa adalah besar sekali pengaruhnya terhadap kelancaran penjualan, dalam hal ini masalah kemasan tidak boleh dilupakan. Dengan demikian kemasan yang menarik akan mempercepat kelancaran penjualan barang. Charles A. Bresin staf dari Packaging magazine Amerika mengatakan "Bahwa kemasan tidak hanya merupakan pelayanan tapi juga sebagai salesman dan pembawa kepercayaan."

\subsubsection{Digital Library}

Berdasarkan Wikipedia Indonesia, ensiklopedia bebas berbahasa Indonesia, menyebutkan :

Perpustakaan digital (Ingeris: digital library atau electronic library atau virtual library) adalah perpustakaan yang mempunyai koleksi buku sebagian besar dalam bentuk format digital dan yang bisa diakses dengan komputer. Jenis perpustakaan ini berbeda dengan jenis perpustakaan konvensional yang berupa kumpulan buku tercetak, film mikro (microform dan microfiche), ataupun kumpulan kaset audio, video, dll. Isi dari perpustakaan digital berada dalam suatu komputer server yang bisa ditempatkan secara lokal, maupun di lokasi yang jauh, namun dapat diakses dengan cepat dan mudah lewat jaringan komputer." 9

Singkatnya koleksi digital sebenarnya dapat dipahami sebagai koleksi informasi dalam bentuk elektronik atau digital yang mungkin terdapat juga dalam koleksi cetak, yang dapat diakses secara luas menggunakan media komputer dan sejenisnya. Koleksi digital disini dapat bermacam-macam, dapat berupa buku elektronik, jurnal elektronik, database online, statistic elektronik, dan lain sebagainya.

\subsubsection{E-Journal}

Menurut Glossary yang dikeluarkan oleh African Digital Library, yang dimaksud dengan e-journal adalah :

An article or complete journal available fully electronically via a website on the Internet. It could be available free or as part of a paid for service. This trend is older and more established than the trend of

\footnotetext{
${ }^{7}$ Joko Santoso. "Kemas Ulang Informasi Elektronis Sebagai Langkah Inovatif Layanan Perpustakaan :Teknologi Informasi dan Pengaruhnya Pada Pengemasan Informasi." 25 Maret 2008<www.pnri.go.id >

${ }^{8}$ Buchari Alma. Manajemen Pemasaran dan Pemasaran Jasa. Bandung: Alfabeta, 1998. hal. 11

9 "Perpustakaan Digital" 20 juni 2008 <http://encyclopaedia.thefreedictionary.com/digital+library>
} 
providing e-book content via the Internet. ${ }^{10}$

Artikel-artikel untuk jurnal ilmiah merupakan pengetahuan primer, berbeda dengan buku pelajaran yang merupakan pengetahuan sekunder. Pengetahuan primer baru akan ada apabila ada penelitian baru, jadi suatu penerbit tidak dapat begitu saja menerbitkan jurnal ilmiah dan mencari artikel untuk jurnalnya. Apabila tidak ada yang meneliti maka tidak ada jurnal yang perlu diterbitkan.

Saat ini banyak perpustakaan perguruan tinggi berlangganan database online yang berisi berbagai macam jurnal elektronik maupun artikel elektronik. Melalui database online ini perpustakaan mampu menyediakan koleksi digital yang dapat diakses oleh pengguna perpustakaan dalam wilayah area tertentu. Ebscohost dan Proquest adalah dua contoh database

Untuk membangun sistem perpustakaan digital, ada banyak aplikasi yang bisa digunakan, baik yang komersial maupun yang Open Source.

\subsubsection{Katalog Online}

Tujuan utama katalog terkomputerisasi adalah membuat suatu sistem pengkatalogan yang sesuai dengan pemanfaatannya.. Sumber-sumber pembuatan katalog online (terkomputerisasi) didapatkan dari:

a. Katalog manual local yang berbentuk lembaran atau kartu tercetak. File yang telah dibuat oleh Kataloger, baik yang telah berformat MARC maupun belum

b. Penggabungan (integrasi) file database katalog antar perpustakaan;

c. Membeli katalog komersial berformat MARC.

\section{TUJUAN DAN MANFAAT PENELITIAN}

\subsection{Tujuan Penelitian}

Tujuan yang ingin dicapai adalah untuk mengetahui kekuatan, kelemahan, peluang dan kesempatan dalam perencanaan, pengorganisasian, pelaksanaan, dan evaluasi untuk pengemasan produk berbasis teknologi informasi yang telah dijalankan di UPT Perpustakaan Universitas Riau.

\subsection{Manfaat Penelitian}

Manfaat dari penelitian ini adalah

1. Sivitas Akademika UR dan juga umum menjadi paham dan mengetahui jenis layanan yang dimiliki oleh UPT UR dengan layanan berbasis Teknologi Informasi sehingga semua sivitas dapat memanfaatkan produk yang sudah dilayankan UPT erpustakaan dengan baik.

2. Pengguna dapat mengetahui kekuatan (strengths), kelemahan (weaknesses), peluang (opportunities), dan ancaman (threats) dalam perencanaan, pengorganisasian, proses pendigitalisasian, dan pengevaluasian/proses pengemasan produk berbasis Teknologi Informasi di perpustakaan. UR.

\footnotetext{
10 “African Digital Library Glossary”. (2002).20 Juni 2008 <http://www.africandl.org.za/glossary.htm>
} 


\section{METODE PENELITIAN}

\subsection{Tempat dan Waktu}

Penelitian ini dilaksanakan pada bulan Maret 2017 sampai dengan bulan September 2018 yang meliputi kegiatan persiapan, penelitian lapangan, pengolahan data dan penyusunan laporan Adapun lokasi penelitian dilakukan di Universitas Riau, Jl. HR Subrantas Panam dan Universitas UIN Suska Riau.

\subsection{Pengumpulan data}

Data yang dipergunakan dalam penelitian ini adalah data primer dan data sekunder. Untuk mengumpulkan data primer maka dilakukan obervasi langsung di lapangan yang meliputi pengamatan langsung dilapangan dengan melakukan wawancara langsung dengan stakeholder dan staf yang bertugas.

Data Primer digunakan untuk mengetahui kondisi pengemasan yang dilakukan diperoleh melalui kegiatan wawancara, baik wawancara dengan panduan kuesioner (daftar isian) maupun wawancara mendalam (indepth interview). Kepada pimpinan, staf yang bertugas melakukan pendigitalisasian.

Selanjutnya data sekunder diperoleh dengan metode studi pustaka (desk study) yang diperoleh dari UPT Perpustakaan Universitas Riau (UR), Perpustakaan UIN Suska Riau, Puskom UR, UPT Universitas Lancang Kuning dan dari berbagai penelitian, dokumen-dokumen lainnya dengan tema yang sama untuk kemudian dianalisis.

\subsection{Prosedur penelitian}

Pengemasan informasi adalah kegiatan yang dimulai dari menyeleksi berbagai informasi dari sumber yang berbeda, mendata informasi yang relevan, menganalisis, mensintesa, dan menyajikan informasi yang sesuai dengan kebutuhan pemakai. Informasi yang dikemas kembali memberi kemudahan dalam penyebaran informasi dan temu kembali informasi. Aktivitas evaluasi dilakukan secara partisipatif, dengan melibatkan stakeholder dan pengguna, karena proses ini merupakan pembelajaran untuk melakukan refleksi mengenai apa yang telah dilakukan, harus disadari kekuatan dan kelemahannya, yang selanjutnya berpikir dan merencanakan apa yang harus dilakukan untuk perbaikan selanjutnya

\subsection{Analisis Data}

Analisis merupakan proses pencarian dan perencanaan secara sistematis semua data dan bahan yang telah terkumpul agar peneliti mengerti benar makna yang telah dikemukakannya dan dapat menyajikannya kepada orang lain secara jelas. ${ }^{11}$ Analisis yang digunakan dalam penelitian ini adalah dengan menggunakan pendekatan deskriptif evaluatif tentang model pengemasan produk berbasis teknologi informasi di UPT Perpustakaan UR.

Dalam proses pengumpulan data penulis menggunakan teknik wawancara, dokumen, dan observasi langsung ke lokasi penelitian. Data yang

${ }^{11}$ Lexy J Moleong. Metode Penelitian Kualitatif. Bandung: Remaja Karya., 1991.

Hal. 112 
dikumpulkan dalam penelitian ini berupa deskripsi data yang telah disusun secara teratur dengan menggunakan pola penelitian induktif yang diolah secara interaktif. Artinya jalinan data antara yang satu dengan yang lain senantiasa dipertahankan baik pada pra pelaksanaan, pelaksanaan maupun pada waktu penyusunan hasil penelitian. Setelah data terkumpul dilakukan proses seleksi data, kemudian data tersebut disajikan secara sistematis sehingga akan lebih mudah dipahami. Dari penyajian data yang telah diolah tersebut diinterpretasikan dan ditarik suatu kesimpulan. komponen:

Teknik analisis yang digunakan dalam penelitian ini melalui tiga

1. Reduksi Data

2. Sajian Data

3. Penarikan Simpulan dan Verifikasi

Ketiga komponen tersebut membentuk interaksi dengan proses pengumpulan data sebagai sebuah siklus.

\section{HASIL DAN PEMBAHASAN}

\subsection{Hasil}

Perpustakaan Universiatas Riau didirikan pada tahun 1962 bersamaan dengan berdirinya Universitas Riau yang masih di bawah naungan Yayasan Universitas Riau dan hanya menempati ruang seluas 100 meter persegi. Pada tahun 1980 Perpustakaan Universitas Riau hanya memiliki gedung seluas 500 meter persegi yang terletak di lokasi kampus lama jalan Pattimura No. 9 Pekanbaru. Sejak tahun 1992 Perpustakaan Universitas Riau dipindahkan ke kampus baru yakni Kampus Bina Widya Panam Jalan HR Soebrantas KM 12,5 Simpang Baru, Pekanbaru sejalan dengan dipindahkannya kantor Rektorat dan beberapa fakultas.

Perpustakan UR memiliki gedung sebanyak empat unit masing-masing terdiri dari dua lantai. Dari empat unit yang ada perpustakaan hanya menempati dua gedung dengan luas keseluruhannya 4.000 meter persegi dengan kapasitas 250 tempat duduk, dibangun di atas lahan seluas $2 \mathrm{Ha}$.

Perpustakaan saat ini melayani lebih dari 27.500 mahasiswa, 1.400 dosen dan 654 karyawan. Perpustakaan Universitas Riau menyimpan lebih dari 132.000 judul atau 365.000 eksemplar koleksi bahan pustaka, dengan pertambahan setiap tahun sekitar 8.500 eksemplar. Selain itu perpustakaan Universitas Riau memiliki koleksi elektronik yang terdiri dari jurnal dan bahan-bahan koleksi “local content”. Jumlah e-journal yang dilanggan lebih dari 5.000 judul dalam berbagai disiplin ilmu yang diperlukan terutama oleh sivitas akademika UR. Kedua jenis koleksi elektronik jurnal tersebut dapat diakses melalui jaringan www: lib.unri.ac.id dan www:ur-lib.com.

Perpustakaan UR sudah dua tahun ini menggunakan sistem otomasi perpustakaan dengan menggunakan program SliMS dan untuk pelayanannya sudah dikembangkan komplemennya dari pengembangan program SliMS Cendana, aplikasi pelayanan mandiri yang telah diterapkan untuk transaksi peminjaman, perpanjangan dan pengembalian buku dalam upaya untuk meningkatkan pelayanan. Penerapan aplikasi Pelayanan Mandiri ini sejak tanggal 30 Agustus 2013.

Perpustakaan UR mendapat nilai terbaik dalam akreditasi perpustakaan Tahun 2013, yaitu Kategori "A" . Hasil penilaian akreditasi Perpustakaan UR oleh Tim Asesor Perpustakaan Nasional RI dari 17 September hingga 18 Desember 2013 tertuang dalam Sertifikat Akreditasi Perpustakaan Perpustakaan Nasional RI Nomor 19/1/ee/XII.2013 


\subsection{Pembahasan}

\section{A. Pemetaan Khalayak UPT Perpustakaan Universitas Riau}

\section{Segmentasi Perpustakaan}

Dalam pendekatan pemasaran ada beberapa hal yang menjadi pertanyaan utama antara lain: Siapa pemakai utama atau konsumen dari perusahaan? Apa yang pemakai inginkan? Apa yang dapat dilakukan perusahaan agar keinginan pemakai terpenuhi? Dan dengan cara apa perusahaan dapat memenuhi kebutuhan pemakai? Praktik di dunia pemasaran dan jasa tersebut juga terjadi di perpustakaan. Pembeli atau konsumen di perpustakaan disebut pengunjung atau pengguna (user). Perpustakaan harus jeli melihat pasar dan menentukan segmentasi penggunanya. Segmentasi pasar adalah proses pemisahan pasar total menjadi kelompok-kelompok pasar dengan kebutuhan yang sama. Pasar segmen adalah individu atau organisasi dengan ciri serupa sehingga kebutuhanyapun serupa. Di perpustakaan perguruan tinggi, segmen terdiri dari dua identifikasi, yaitu penguna aktual dan pengguna potensial. Sivitas akademika perguruan tinggi (dosen, karyawan, dan mahasiswa), alumni, mahasiswa/dosen di luar PT tersebut, merupakan segmen aktual yang harus dilayani. Sedangkan segmen potensial adalah sekelompok orang atau organisasi lain yang mungkin akan menggunakan produk atau jasa kita di masa yang akan datang. Di mungkinkan pelajar-pelajar di sekitar Pekanbaru, masyarakat umum (seperti warga sekitar), organisasi politik di Pekanbaru, atau berbagai yayasan pendidikan lainnya akan memanfaatkan jasa layanan produk berbasis teknologi informasi. Segmentasi pasar di UPT Perpustakaan UR adalah sebagai berikut :

1. Dosen seluruh fakultas di lingkungan UR

2. Mahasiswa S3, S2, S1, maupun DIII seluruh fakultas di lingkungan UR

3. Karyawan baik administrasi maupun fungsional di lingkungan UR

4. Pelajar, mahasiswa, dan dosen dari luar UR

5. Masyarakat umum

Adapun segmentasi Pengemasan Produk Berbasis IT adalah sebagai berikut :

Tabel 4. Segmentasi Pengemasan Produk Berbasis TI

\begin{tabular}{|l|l|}
\hline \multicolumn{1}{|c|}{ Jenis Pengemasan } & \multicolumn{1}{c|}{ Segmentasi } \\
\hline \$ Digital library & Sivitas akademika UR dan Umum \\
$\S$ E -Journal & Sivitas akademika UR \\
$\S$ Katalog Online & Sivitas akademika UR dan Umum \\
\hline
\end{tabular}

Sumber : olah data peneliti, 2017

\section{Targeting Perpustakaan}

UPT Perpustakaan sebagai unit perpustakaan universitas dalam hal ini targetnya sudah jelas, yaitu seluruh sivitas akademika UR. Adapun targeting sivitas akademika meliputi :

1. Dosen seluruh fakultas di lingkungan UR

2. Mahasiswa S3, S2, S1, maupun DIII seluruh fakultas di lingkungan UR

3. Karyawan baik administrasi maupun fungsional di lingkungan UR

Jumlah pengguna dapat dapat dilihat sebagai berikut:

Tabel 5 Jumlah pengguna Perpustakaan s/d 1 Agustus 2017 


\begin{tabular}{|l|r|r|l|}
\hline \multicolumn{1}{|c|}{ Status } & \multicolumn{1}{c|}{ Jumlah } & $\begin{array}{c}\text { Juml Terdaftar sbg anggt } \\
\text { Perp }\end{array}$ & $\%$ \\
\hline Mahasiswa & 27.500 & 8.460 & $31 \%$ \\
\hline Dosen & 1.400 & 5 & $4 \%$ \\
\hline Karyawan & 654 & 23 & $0.4 \%$ \\
\hline Jumlah & 29.554 & 8.488 & $3 \%$ \\
\hline
\end{tabular}

Sumber : olah data peneliti, 2017

Tabel 6. Jumlah Pengguna Jurnal Elektronik UPT Perpustakaan UR Th. 2017

\begin{tabular}{|l|c|}
\hline \multicolumn{1}{|c|}{ Bulan } & Penelusuran/Bulan... \\
\hline & Tahun 2017 \\
\hline Januari & 102 \\
\hline Februari & 92 \\
\hline Maret & 425 \\
\hline April & 398 \\
\hline Mei & 398 \\
\hline Juni & 234 \\
\hline Juli & 166 \\
\hline Jumlah & 1815 \\
\hline
\end{tabular}

Sumber : Bag. Pelayanan Internet, 2017

Berdasarkan data di atas, dapat dikatakan bahwa UPT harus lebih giat lagi mempromosikan keberadaan produk-produk berbasis teknologi informasi yang dimiliki UPT UR sebab masih sedikit yang terdafdar sebagai anggota dibanding dengan jumlah seluruh sivitas akademika yakni hanya 3\% maka UPT Perpustakaan UR perlu mengupayakan agar produk berbasis teknologi informasi yang tersedia termanfaatkan secara maksimal ke pengguna, terutama sivitas akademika.

Selain itu perpustakaan juga menerapkan pricing yang murah dalam pembuatan kartu anggota perpustakaan. Denda keterlambatan pengembalian buku juga lebih murah dibandingkan dengan denda ketelambatan buku di perpustakaan fakultas maupun universitas lain.

\section{B. Fungsi Manajemen}

\section{Perencanaan}

UPT Perpustakaan UR menjalankan promosi pada setiap tahunnya. Jenis kegiatan promosi bisa dikatakan hampir sama dengan kegiatan promosi pada tahuntahun sebelumnya. UPT Perpustakaan UR dalam merencanakan program promosi yaitu salah satunya pengemasan produk berbasis teknologi informasi sudah terencana dalam renstra dan biasanya dilakukan tiap semester setelah selesai sidang mahasiswa menyerahkan dalam bentuk soft copy di dalam sebuah cd. Kemudian bagian Publisher IT yang akan mengatur pembagian tugas untuk didigitalkan sehingga semua berjalan lancar sesuai perencanaan yang telah dibuat untuk setiap semester harus bisa diselesaikan sebelum datang semester berikutnya demikian kata firdaus syam (wawancara tanggal 17 Maret 2017),

\section{Pengorganisasian}

Fungsi manajemen terpenting yang kedua adalah pengorganisasian, Hasil pengorganisasianbukanlah sebuah struktur organisasi melainkan terorgani sasikannya 
semua aktivitas di dalam suatu wadah organisasi, sehingga semua tugas dan fungsi berjalan guna mencapai tujuan. Kegiatan promosi di atas diketuai oleh personil yang mempunyai kompetensi di bidangnya, dibantu oleh beberapa staf. Seperti yang diungkap oleh Sekretaris Kepala UPT Perpustakaan "staf ditugaskan disesuaikan dengan kemampuannya".(wawancara, 12 April 2017). Pada pengorganisasian ini masing-masing harus sudah tahu mana pekerjaan masing-masing, disini untuk pendigitalan dibagi per fakultas dan per jurusan, pengkodean untuk masing masing jurusan berbeda, Ada tiga orang staf, kemudian mereka kerja sendiri-sendiri sampai selesai untuk di upload ke sistem kata Firdaus syam. Wawancara 20 April 2017)

\section{Pelaksanaan}

Pelaksanaan disini dilakukan oleh staf yang memang sudah berkompetensi dibidangnya, seperti Firdaus Syam, S.IP. Lalu semua bahan / skripsi yang diterima dari mahasiswa dalam bentuk soft copy dalam sebuah cd, dibagian ini semua soft copy yang ada di kelompokkan per fakultas, dimana Firdaus syam dan 2 orang temannya berada dibagian ini, setelah itu mereka masing-masing melakukan tugasnya misal Firdaus yang saat itu kami wawancara dia mengatakan bahwa dia bertugas untuk Fakultas Teknik, Fakultas Pertanian, Fakultas Kedokteran, Fakultas Hukum, Program Pasca Sarjana. Untuk mendapatkan data yang lebih baik kami lakukan wawancara mendalam dengan Firdaus Syam, S.IP, beliau mengatakan bahwa adapun kendala yang sering dihadapi dalam mendigitalkan adalah masalah koneksi jaringan yang lelet dimana untuk satu skripsi dibutuhkan agak lama waktunya merubah format dari word ke Pdf sehingga untuk satu skripsi lumayan waktu yang diperlukan, terus setelah diubah ke pdf selanjutnya diberi pengindentitas skripsi tersebut dengan watermark".(wawancara 07 Maret 2017).

Sementara untuk Jurnal yang ada difakultas berjumlah \pm 54 jurnal, tetapi yang menyerahkan ke UPT kadang tidak semuanya rutin jadi yang di ejournalkan hanya jurnal yang diserahkan saja demikian kata staf Publisher IT Anton Yuliarto S. Kom.( wawancara 20 Apil 2017).

\section{Evaluasi}

Evaluasi dilakukan setiap per semester dimana semua tugas akhir, skripsi, tesis, disertasi, yang masuk sudah harus selesai di input dan diupload untuk dapat dilayankan dan dipromosikan keberadaannya bagi sivitas akademika dan bagi siapa saja yang membutuhkan informasi tersebut, pimpinan selalu mengingatka agar para staf jangan sampai keteteran dalam menangani pendigitalan tersebut. Kalau ada cd yang tidak bisa dibaca dan tak bisa dibuka maka staf berusaha menghubungi mahasiswa tersebut agar di kirim ulang baik melalui email atau memberikan cd yang baru yang sudah berisi.(wawancara dengan staf 17 Maret 2017), demikianlah evaluasi dilakukan tiap semester.

\section{Analisa SWOT}

Adapun yang dilakukan oleh competitor/pesaing untuk perencanaan, pengorgansasian, pelaksanaan dan evaluasi khususnya perpustakaan UIN Suska Riau bahwa mahasiswa terlibat langsung dalam proses pendigiitalan, dimana setelah selesai sidang tugas akhir mahasiswa harus merubah sendiri tugas akhir dalam format PDF di perpustakaan UIN Suska 1t 3, dimana semua peralatan sudah disediakan oleh perpustakaan setelah itu mahasiswa yang bersangkutan mengupload sesuai aturan yang berlaku, dan pemberian watermark juga dilakukan sendiri, staf hanya akan menerima konfirmasi dari mahasiswa kalau mereka sudah mengupload tugas akhir tersebut ke sistem sesuai wawancara dengan kepala perpustakaan UIN Suska ibu Dr. Surani,S.Ag, M.Si (wawancara 07 Maret 2018), kemudian staf mengkoreksi hasil penguploadan dari mahasiswa.

Hubungan antara Strength, Weaknesses, Opportunities, dan Treaths dalam analisis SWOT dapat digambarkan melalui bagan berikut ini (Afhie, 2012) 


\begin{tabular}{|l|l|l|}
\hline HUBUNGAN & \multicolumn{1}{|c|}{ S (KEKUATAN) } & \multicolumn{2}{|c|}{ (KELEMAHAN) } \\
\hline O (PELUANG) & $\begin{array}{l}\text { Sebuah lembaga/perpustakaan } \\
\text { harus dapat menggunakan } \\
\text { kekuatan untuk memanfaatkan } \\
\text { peluang dan sebaliknya } \\
\text { memanfaatkan peluang dan } \\
\text { menjadikannya sebagai sebuah } \\
\text { kekuatan (Strength). }\end{array}$ & $\begin{array}{l}\text { Peluang digunakan untuk } \\
\text { menekan berbagai macam } \\
\text { kelemahan-kelamahan yang ada } \\
\text { atau dengan kata lain } \\
\text { menghilangkan kelemahan } \\
\text { dengan memanfaatkan peluang. }\end{array}$ \\
\hline T (ANCAMAN) & $\begin{array}{l}\text { Menggunakan kekuatan untuk } \\
\text { menghindari ancaman. }\end{array}$ & $\begin{array}{l}\text { Suatu lembaga/ perpustakaan, } \\
\text { sebelum datangnya sebuah } \\
\text { ancaman lembaga/perpustakaan } \\
\text { tersebut harus bisa menutupi } \\
\text { kelemahan-kelemahan yang ada } \\
\text { pada dirinya dengan kekuatan } \\
\text { dan peluang. }\end{array}$ \\
\hline
\end{tabular}

Jadi berdasarkan hasil observasi dan wawancara dapat disimpulkan bahwa sebaiknya perpustakaan UR seharusnya dapat mengikuti cara yang dilakukan oleh perpustakaan UIN Suska, dimana mahasiswa terlibat langsung dalam proses pendigitalisasian sehingga dapat mengurangi staf dalam melakukan tugas tersebut namun harus tetap diawasi oleh staf, karna kalau tidak bisa terjadi kekacauan dalam penyusunan pengkodean dan lain-lain yang berakibat fatal.

\section{KESIMPULAN}

Berdasarkan hasil observasi dan wawancara dilapangan di peroleh kesimpulan :

Bahwa perencanaan, pengorganisasian dan pelaksanaan serta pengevaluasian dalam pengemasan produk berbasis IT di UPT Perpustakaan UR belum sepenuhnya dapat terlaksana dengan baik ini disebabkan beberapa kendala yang sifatnya teknis seperti cd rusak, jaringan lelet, dan perubahan format data dari word ke Pdf yang memakan waktu agak lama tetapi ini semua dapat diatasi oleh staf, untuk itu harus dilakukan peningkatan kemampuan internetnya agar dapat meningkatkan kecepatan akses, serta harus melibatkan mahasiswa dalam pendigitalisasian seperti yang dilakukan oleh perpustakaan UIN Suska agar dapat meningkatkan efisiensi dan efektifitas dalam perencanaan, pengorganisasian, pelaksanaan dan pengevaluasian untuk pengemasan produk berbasis Teknologi Informasi Di Perpustakaan UR namun tetap dilakukan pengawassan oleh staf.

\section{DAFTAR PUSTAKA}


“AfricanDigital Library Glossary". (2002).20 Juni 2008 http://www.africandl. org.za/glossary.htm

Afhie, 2012 dalam http://afhie-cirebon.blogspot.com/2012/ 12/penerapan-analisisswot-pada-lembaga.html

Alma, Buchari. 1998.Manajemen Pemasaran dan Pemasaran Jasa. Bandung:Alfabeta,

Badollahi Mustafa.1996. Promosi Jasa perpustakaan. Jakarta: Universitas Terbuka, Fandy Tjiptono. 2008.Pemasaran Strategik. Yogyakarta: Andi,. hal. 5 1995.Strategi Pemasaran Yogyakarta : andi Offset, Hal.200

Joko Santoso. "Kemas Ulang Informasi Elektronis Sebagai Langkah Inovatif Layanan Perpustakaan

Lasa Hs. 2005. Manajemen Perpustakaan. Yogyakarta : Gama Media,

Moleong, Lexy J. 2004. Metodologi Penelitian Kualitatif. Bandung: Rosda.

Mustafa, Badollahi. Promosi Jasa perpustakaan. Jakarta: Universitas Terbuka,

Teknologi Informasi dan Pengaruhnya Pada Pengemasan Informasi." 25 Maret $2008<w w w . p n r i . g o . i d>$

"PerpustakaanDigital"20juni2008<http://encyclopaedia.thefreedictionary.com/digital+ library>

PR Smith. 1998. Marketing Communications: An Integrated Approach. London: Kogan Page, P. 7

Yuhelmi, Y., \& Rosman, H. (2015). Evaluasi Promosi di Perpustakaan Soeman HS Pekanbaru. Jurnal Ilmu Budaya, 12(1), 45-57. 